\title{
Shipment and Storage Containers for Tritium Production Transportation Casks
}

by

W. M. Massey

Westinghouse Savannah River Company

Savannah River Site

Aiken, South Carolina 29808

DOE Contract No. DE-AC09-96SR18500

This paper was prepared in connection with work done under the above contract number with the U.S.

Department of Energy. By acceptance of this paper, the publisher and/or recipient acknowledges the U.S. Government's right to retain' a nonexclusive, royalty-free license in and to any copyright covering this paper, along with the right to reproduce and to authorize others to reproduce all or part of the copyrighted paper. 


\section{DISCLAIMER}

This report was prepared as an account of work sponsored by an agency of the United States Government. Neither the United States Government nor any agency thereof, nor any of their employees, makes any warranty, express or implied, or assumes any legal liability or responsibility for the accuracy, completeness, or usefulness of any information, apparatus, product, or process disclosed, or represents that its use would not infringe privately owned rights. Reference herein to any specific commercial product, process, or service by trade name, trademark, manufacturer, or otherwise does not necessarily constitute or imply its endorsement, recommendation, or favoring by the United States Government or any agency thereof. The views and opinions of authors expressed herein do not necessarily state or reflect those of the United States Government or any agency thereof.

This report has been reproduced directly from the best available copy.

Available to DOE and DOE contractors from the Office of Scientific and Technical Information, P.O. Box 62, Oak Ridge, TN 37831; prices available from (615) 576-8401.

Available to the public from the National Technical Information Service, U.S. Department of Commerce, 5285 Port Royal Road, Springfield, VA 22161. 


\section{DISCLAIMER}

Portions of this document may be illegible electronic image products. Images are produced from the best available original document. 
WSRC-TR-98-00001

Engineered Equipment and Systems Department

$\begin{array}{ll}\text { KEYWORDS: } & \text { Packaging } \\ & \text { Transportation } \\ & \text { Tritium } \\ & \text { TPBAR } \\ & \text { Cask } \\ & \text { Container }\end{array}$

\title{
SHIPMENT AND STORAGE CONTAINERS FOR TRITIUM PRODUCTION TRANSPORTATION CASKS (U)
}

\author{
William M. Massey
}

Issued: January 16, 1998

Approvals:

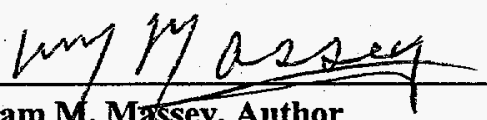

William M. Massey, Author

Packaging and Transportation Group

R. N. Lutz, Technical Reviewer

Packaging and Transportation Group

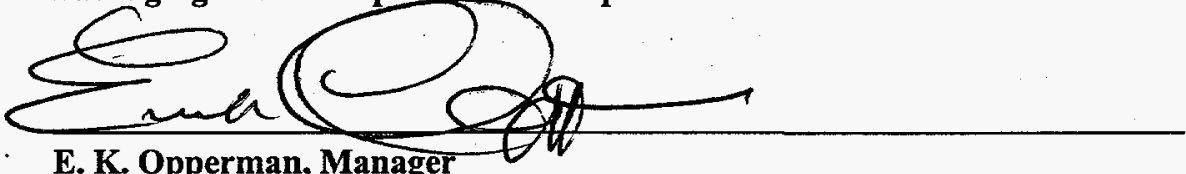

E. K. Opperman, Manager

Packaging and Transportation Group

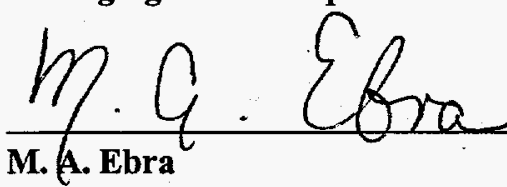

Engineering Equipment Manager
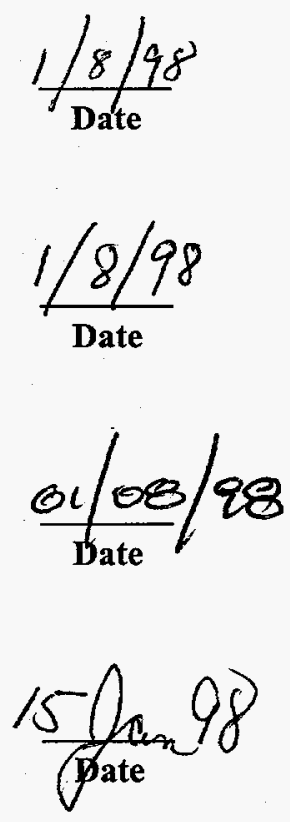
WSRC-TR-98-00001

Engineered Equipment and Systems Department

TABLE OF CONTENTS

Abstract

Introduction

Background

Determining if a Container is Needed

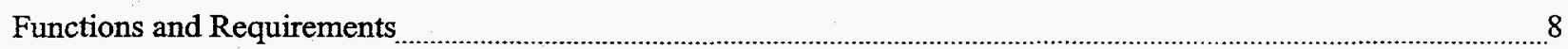

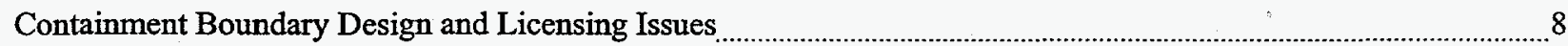

Cost and Schedule Impacts

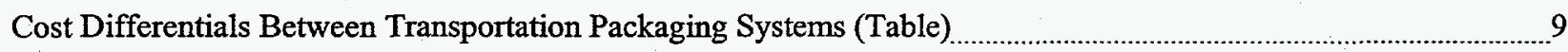

Conclusions and Recommendations

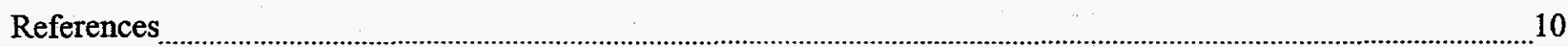




\section{ABSTRACT}

A shipping and storage container for the Tritium production transportation casks may be required but requirements for protection of the irradiated rods and radioactive contamination have not been finalized. This report documents the various possibilities for the container depending on the final requirements. 


\section{INTRODUCTION}

This position paper addresses issues related to design, licensing, and cost of internal components for the transportation cask system for the Commercial Light Water Reactor (CLWR) Tritium Production Program. The needs for an internal container for the transportation package system are discusšed, and requirements and issues related to the internal components design, licensing, and cost are identified. Based on the conclusions of these discussions, a recommendation is pressented with regard to container provisions for the CLWR tritium production transportation cask system.

Throughout this discussion, the term internal container is used to describe a removable inner container within a transportation package that may or may not be sealable, depending on final design requirements. The term basket is used to describe a non-removable, or built-in, fixture that is integral with the transportation cask body.

\section{BACKGROUND}

The System Description Requirements Document (SDRD), [Reference 1] calls for the use of shipping and storage containers for the irradiated tritium producing burnable absorber rods (TPBARs) which can be inerted and will be used for storage at the Tritium Extraction Facility (TEF). These containers will be shipped inside the shipping cask. There have been recent discussions as to whether or not an internal container should be provided in the transportation cask for confining or handling (TPBARs). The TPBARs are to be configured in a geometric array for handling and transportation that closely resembles that of light water reactor (LWR) fuel elements. As such, the container and cask designs will likely be very similar to existing cask and internal basket or canister designs. Because of this similarity, issues faced by the commercial industry for spent nuclear fuel transportation canister and cask designs are very similar to the issues that will arise for the tritium production container and cask designs.

Several commercial industry spent nuclear fuel transportation cask systems are under development which utilize internal canisters. Examples of these are:

$\begin{array}{ll}\text { - } & \text { Holtec HI-STAR } 100 \text { System } \\ \text { - } & \text { VECTRA NUHOMS® MP187 System } \\ \text { - } & \text { Sierra TranStor }{ }^{\mathrm{TM}} \text { System } \\ \text { - } & \text { Nuclinghouse Large/Small Multi-Purpose Canister System } \\ & \text { Nurance Corporation Universal Multi-Purpose System. }\end{array}$

Experience with these type transportation cask and canister systems is likely to affect the decision of whether or not to provide a container for the tritium production cask, and if a container is provided, how the system should be designed. Current Nuclear Regulatory Commission (NRC) licensing precedent for commercial canister systems is to not take credit for the containment capability of the internal canister during transportation. The canisters are merely provided for convenience in handling, supporting, and storing the spent nuclear fuel assemblies and for providing contamination control. 


\section{DETERMINING IF A CONTAINER IS NEEDED}

The need for an internal container is almost always dictated by handling and structural support requirements for the contents of the transportation package, rather than by containment requirements for the overall transportation package. For example, an internal container may be needed to provide an inert environment for protecting the TPBARs against corrosion, to confine any contamination on the TPBARs and prevent its spread, or to provide a convenient mechanism for handling the TPBAR array during various stages of loading, unloading, and processing. The relatively thin-walled container can be loaded, closed with a sealed lid, and backfilled with inert gas to protect the TPBARs. Use of an internal container would probably increase handling time at the reactor site due to increased closure, sealing and drying requirements associated with two components. Conversely, handling time at the tritium extraction facility would probably be reduced if an internal container is used, because the TPBAR array would arrive already encased.

Structural support must be provided for the TPBAR array within the transportation cask. This support can either be provided by a non-removable structure that is integral with the cask body or by a removable basket, which could be part of a container. Use of an internal container for supporting the array provides more flexibility than a basket integral with the cask. If an internal container is used, replacement of damaged structural support members can be easily performed by simply replacing the container. However, damage to an integral basket could result in removal of the cask from service for an extended period. In addition, a removable internal container provides the flexibility to insert different structural support systems for utilizing the cask to transport TPBAR arrays as well as other contents, such as irradiated hardware wastes (assuming certification of the package is obtained for the alternate contents). These flexibilities may make utilizing an internal container attractive from an overall cost perspective, versus using a single cask system that has an integral basket. Of course, integral baskets of a single cask system could also be made removable, but this would be somewhat more complex than simply pulling out a container and inserting one of a different design.

Residual buildup of contamination often occurs on package systems used in reactor spent fuel pools. Over time, high levels of respirable contamination (i.e., cask weeping) can result in loss of use of a package. Commercial experience has shown that it is somewhat easier to decontaminate the interior of package systems that utilize removable containers. With a package system utilizing removable containers, the inner surface of the cask cavity and the outer surface of the container are uniform and relatively easy to decontaminate.

The need for an internal container should be considered separate from any transportation containment requirements, since a single pressure boundary transportation cask must provide containment capability by itself under current NRC licensing philosophy. Thus, the decision of whether or not to provide an internal container should be based solely on package content protection, support, contamination control, and handling requirements. These issues are all determined based on owner preferences. Transportation containment requirements should not be a consideration in determining the need for an internal container.

At this writing the SDRD calls for the use of a inerted internal shipping container. If a container is not used in the cask during transportation, the cask itself can be inerted to inhibit corrosion. A need remains for an inerted TEF storage container that serves to inhibit corrosion should the TPBARs require lengthy storage periods. The storage container would presumably be of simpler design with some less stringent manufacturing requirements and easier fabrication (without the need to interface outside TEF) and thus cost less to produce.

Additional evaluations may obviate the need for inerting the TPBARs but call for the need of a container to reduce contamination. In this case, a shipping array that can be dewatered at the Reactor will be required but inerting capability will not be required. This array would also be retained by the TEF in a container for storage until processing.

The final container requirements will determined at a later date. 


\section{FUNCTIONS AND REQUIREMENTS}

The two primary functions of an internal container would be to:

- Confine the contents of the package, and

- Provide structural support for the TPBAR array.

Confining the contents of the package simply means to provide a sealed enclosure that can contain backfill gases, if desired, and prevent escape of contamination. The low pressures associated with backfilling usually require only a thin-walled container shell; however shielding concerns usually dictate a thick lid be used. Requirements for containment functions for accident loads and pressures are normally applied to the design of the outer cask, and not to the internal container design. (This is discussed in more detail later.) For a package system without an internal container, there would obviously be no confinement functions provided by the basket.

Providing structural support for the TPBAR array means to provide a configuration that adequately supports the array during all normal and postulated accident conditions. This support could be provided either by the container with a basket or by a basket assembly alone. If a container with a basket is used, the basket comprises the majority of the container design. The container or basket configuration would serve to convert the square cross-section of the array to the circular cross-section of the transportation cask internal cavity, which is typical for most pressure retaining package designs. The structural support must be substantial enough to transfer accident impact loads to the outer cask and protect the array against significant damage.

In addition to these primary functions for confinement and support, there are numerous requirements for the container that are associated with interfaces at the reactor and tritium extraction facility. These will dictate container size, lifting device attachments, shielding, etc. Since shipments of high-level radioactive materials cannot contain significant amounts of water under current NRC licensing precedent, the containers must be dewatered and vacuum dried after they are loaded and prior to closing the outer transportation cask. This can be accomplished, as proven by use of existing cask and canister systems.

Transportation package design must be in accordance with 10 CFR Part 71 requirements. Analysis, design, testing, fabrication, operation, and maintenance activities required by 10CFR71 are well known and have been successfully implemented throughout the commercial industry. Whether the transportation package system is a single cask system without an internal container or a two-part cask and container system will significantly impact the system design, licensing, fabrication, testing, and life-cycle operation.

\section{CONTAINMENT BOUNDARY DESIGN AND LICENSING ISSUES}

Design of a transportation package without an internal container is relatively straight forward. For this case, the transportation cask obviously must provide all the containment and protection functions required by 10CFR71. Such requirements include designing and testing the cask shell, lid, seals, and closure components for containment integrity under all postulated normal and accident conditions. Design of the transportation cask containment boundary is usually performed for a worst-case condition that assumes $100 \%$ of the rod cladding fails. This worstcase design basis approach alleviates many time-consuming regulatory questions during the licensing phase.

If an internal container is provided, then a decision must be made whether or not to consider the internal container as part of the "contents" or part of the "transportation package." Under the current licensing strategy, no credit is taken for any containment capability provided by an inner container. This strategy allows the designer to avoid computer modeling of the inner container, and avoids the need to prove that the inner container does not fail during design basis accident events. As such, commercial package system designs assume the container is part of the "contents." The internal container design has to be included in the licensing and testing of the transportation cask, but only as an internal component that provides structural support and configuration control for the contents. 
On the other hand, if the internal container is considered as part of the containment pressure boundary, or part of the transportation "package," an entirely different approach must be taken with regard to container design, licensing, testing, and operation. Extensive analysis of the container would have to be performed for design basis events. A justifiable basis would have to be developed to determine how much containment capability would be credited to the container and how much would be credited to the outer cask. This basis would undoubtedly be scrutinized by the licensing agent, and would likely result in the outer cask having to be designed for the full accident basis anyway (e.g., 100\% TPBAR clad failure) in the event the internal container pressure boundary failed. With the internal container considered as part of the transportation package containment pressure boundary, the container may have to be tested separately from the outer cask. This could include pressure testing, drop and puncture testing, heat testing, and submersion testing. These tests are time-consuming and expensive. Regulations allow for analysis and scale model testing, but this is also time consuming and expensive. This may not satisfy regulatory licensing concerns, since scale modeling cannot be applied to seals and sealing surfaces.

\section{COST AND SCFEDULE IMPACTS}

Cost and schedule differentials can be compared for a transportation package system with an internal container that is part of the "contents" (i.e., not a containment boundary component) versus a system with only an integral basket in the cask. There would be cost differentials applicable to the cask component of each type system and to the internal container or basket component.

For the design with an internal container, there would be some cask cost additions due to the size of the cask having to be somewhat larger than for a design without a container. This size increase is necessary because of the additional diameter of the container shell to accommodate the sealing surface and bolt hole locations for the lid, and the additional length required for the container lid. These costs would include additional material, as well as additional fabrication costs. There would also be one-time cost additions for design of the container and its separate systems, over and above those costs associated with designing the cask with only an integral basket. There should be no difference in the certification costs or licensing costs of these two designs, since the certification and licensing work would be similar for either design. The most significant cost differential between the two systems would be the costs for supplying twenty containers, versus only two integral baskets. It is roughly estimated that the containers would cost up to $\$ 40,000$ each, and that the integral baskets would cost $\$ 10,000$ each. The following table summarizes the cost differentials between transportation package systems with and without containers (assuming the containers do not serve as containment boundaries):

\section{Cost Differentials Between Transportation Package Systems}

\begin{tabular}{|l|r|r||}
\hline \multicolumn{1}{|c|}{ Cost Category: } & \multicolumn{1}{|c|}{$\begin{array}{c}\text { System With Container } \\
\text { (no containment credit): }\end{array}$} & System With Basket Only: \\
\hline \hline $\begin{array}{l}\text { Additional cask material } \\
\text { costs }\end{array}$ & $\begin{array}{l}\$ 10,000 / \text { cask x 2 casks } \\
\$ 20,000\end{array}$ & 0 \\
\hline $\begin{array}{l}\text { One-time container design } \\
\text { costs }\end{array}$ & $\$ 75,000$ & 0 \\
\hline $\begin{array}{l}\text { Container or integral basket } \\
\text { fabrication costs }\end{array}$ & $\$ 40,000 /$ container x 20 containers \\
\hline Total Cost Differential: & $\$ 800,000$ & $\$ 10,000 /$ basket $x 2$ basket $=\$ 20,000$ \\
\hline
\end{tabular}


It is anticipated that there would be no appreciable schedule differences between transportation package systems with or without containers, assuming the containers do not serve as containment boundaries. Design and fabrication of the casks and containers, or baskets, could be performed simultaneously, such that there would be no additive schedule effect.

Cost and schedule impacts associated with providing containers as part of the "package" (i.e., part of the containment boundary) are very difficult to determine. It is highly unlikely that süch an approach would offer any benefits or be accepted by the regulatory agency, these costs and schedule impacts are not determined. Such an approach may require a prolonged licensing period, additional testing, and a more robust container design, thereby requiring more material and fabrication. The licensing phase for the cask and container may need to be sequenced one after the other, since the evaluation results from the container licensing would impact the cask licensing, and vice versa. Overall licensing costs would increase significantly since regulatory agent review costs are the responsibility of the licensee.

\section{CONCLUSIONS AND RECOMMENDATIONS}

Use of an internal container for the CLWR tritium production transportation package system will require additional time and resources for design, testing, licensing, fabrication, and operations. The decision whether or not to utilize an internal container should be based solely on package content protection requirements, handling requirements, and the need for flexibility in the use of the system. These considerations should address any requirements for backfilling a container with inert gas to prevent TPBAR corrosion, any needs for TPBAR array handling and storage, any contamination control concerns, and possible alternate use of the cask for transporting irradiated hardware. A removable basket could be used with a cask system to provide flexibility for use of the package. An internal container is not necessary for providing a safe, reliable, and licensable transportation package. The outer package design and cost would not benefit from the use of an internal container to achieve packaging functions; that approach would increase the overall cost.

If it is determined that an internal container is needed, the internal container should be considered as part of the "contents" and not part of the "package." The container should not be considered to provide any containment functions for the transportation package contents. Such an approach will reduce design, testing, licensing, and fabrication costs and schedule. Current NRC licensing strategy results in no overall benefit provided by an internal container as a containment boundary; the outer cask must be designed to contain the full accident pressure.

\section{REFERENCES}

1. CLWR System Description and Requirements Document (SD\&RD), U. S. Department of Energy Tritium Project Office, CLWR-RD-96-5681(08)-06, October, 1996. 